\title{
Proposed dairy calf birth certificate data and death loss categorization scheme
}

\author{
J. E. Lombard, ${ }^{1,2 *}$ F. B. Garry, ${ }^{2}$ N. J. Urie, ${ }^{1}$ S. M. McGuirk, ${ }^{3}$ S. M. Godden, ${ }^{4}$ K. Sterner, ${ }^{5}$ T. J. Earleywine, ${ }^{6}$ \\ D. Catherman, ${ }^{7}$ and J. Maas $^{8}$ \\ ${ }^{1}$ USDA-Animal and Plant Health Inspection Service-Veterinary Services, Center for Epidemiology and Animal Health, \\ National Animal Health Monitoring System, Fort Collins, CO 80526-8117 \\ ${ }^{2}$ Department of Clinical Sciences, College of Veterinary Medicine and Biomedical Sciences, Colorado State University, \\ Fort Collins 80523-1678 \\ ${ }^{3}$ School of Veterinary Medicine, University of Wisconsin, Madison 53706 \\ ${ }^{4}$ Department of Veterinary Population Medicine, University of Minnesota, St. Paul 55108 \\ ${ }^{5}$ Sterner Veterinary Clinic P.C., Ionia, MI 48846 \\ ${ }^{6}$ Land O'Lakes Animal Milk Products Co., Cottage Grove, WI 53527 \\ ${ }^{7}$ Strauss Feeds, Watertown, WI 53908 \\ ${ }^{8}$ School of Veterinary Medicine, University of California-Davis, Davis 95616
}

\section{ABSTRACT}

The majority of dairy heifer calves in the United States are destined to be dairy replacements. However, many dairy heifer and bull calves die before 6 mo of age. Of these calves, about 6\% (more than 500,000 calves) die at birth or shortly after (i.e., currently termed "stillbirth"). An additional $6 \%$ of dairy heifers die during the preweaning period. Death loss in dairy calves is primarily due to stillbirths, failure to adapt to extrauterine life, and infectious disease processes. The reasons for preweaning heifer calf deaths caused by infectious diseases are generally categorized based on easily recognizable clinical signs such as digestive disease/scours or respiratory disease. Most causes of calf death can be mitigated by appropriate preventive care or well-tailored treatments, meaning that the typical death loss percentage could be decreased with better management. Producers could gather information on the circumstances near birth and at death if they had appropriate guidance on what details to record and monitor. This paper provides recommendations on data to collect at the time of birth (i.e., calf birth certificate data). The recording of these critical pieces of information is valuable in evaluating trends over time in morbidity and mortality events in dairy calves. Ideally, necropsy examination would substantially improve the identification of cause of death, but even without necropsy, attribution of cause of death can be improved by more carefully defining death loss categories in on-farm record systems. We propose a death loss categorization

Received September 20, 2018.

Accepted December 13, 2018.

*Corresponding author: Jason.E.Lombard@aphis.usda.gov scheme that more clearly delineates causes of death. Recommendations are provided for additional data to be collected at the time of death. Recording and analyzing birth certificate and death loss data will allow producers and veterinarians to better evaluate associations between calf risk factors and death, with the goal of reducing dairy calf mortality.

Key words: calf birth certificate, dairy calf mortality, death loss categorization, National Animal Health Monitoring System (NAHMS)

\section{BACKGROUND AND MAGNITUDE OF THE PROBLEM}

The majority of dairy heifer calves in the United States are destined to be dairy replacements. However, many dairy heifer and bull calves die before 6 mo of age. Approximately 9 million dairy calves are born every year in the United States. Of these calves, about $6 \%$-more than 500,000 calves - die at birth or shortly after. An additional $6 \%$ of dairy heifers die during the preweaning period (USDA, 2018). A Canadian study by Winder et al. (2018) reported a stillbirth rate of $4.9 \%$ and preweaning mortality of $6.4 \%$, similar to values reported for the United States.

Although information on death loss in dairy bull calves is difficult to monitor due to the movement of bull calves in the United States, a higher percentage of bull calves are stillborn compared with heifer calves (Lombard et al., 2007; Cuttance et al., 2017). The number of bull calves that die before weaning has not been reported in the United States. Bull calf death loss is likely higher than that of heifers because of differences in colostrum management (Shivley et al., 2016) and immunosuppression associated with the stress of 
movement and commingling (Hulbert and Moisá, 2016; Earley et al., 2017).

The reasons for preweaning heifer calf deaths are generally categorized based on easily recognizable clinical signs such as digestive problems/scours or respiratory disease. The most recent National Animal Health Monitoring System (NAHMS) survey in 2014 estimated that $6.4 \%$ of preweaning heifers died in 2013 and that $56.4 \%$ of those deaths were due to digestive disease and $24.0 \%$ were attributable to respiratory problems (USDA, 2018). These 2 death categories have remained at similar percentages since the NAHMS studies were initiated in 1991 (USDA, 2008). The categories used in the latest NAHMS study were based on responses to previous NAHMS studies. Categories with very few attributable deaths were removed and others were added based on their perceived importance. If stillbirths and preweaning heifer deaths are combined, about $12 \%$ of heifer calves $(>500,000)$ are delivered at term and die before 8 to 10 wk of age.

In addition to the NAHMS dairy studies, death loss in calves is captured in a NAHMS death loss study conducted every 5 yr (USDA 2017). The estimates are not directly comparable because the NAHMS dairy reports capture preweaning and weaned heifer deaths separately, whereas the NAHMS death loss reports are for all dairy calves weighing up to $500 \mathrm{lb}$. The NAHMS death loss reports also specifically identify predator causes of death in dairy calves; in $2015,1.2 \%$ of dairy calf deaths were attributable to predators. In 2015, it was estimated that $6.7 \%$ of the calf crop of live-born calves weighing $<500 \mathrm{lb}$ died. More than $60 \%$ of deaths in dairy calves weighing up to $500 \mathrm{lb}$ were attributable to digestive and respiratory problems. According to this report, the value of dairy calf death losses was estimated at $\$ 327.3$ million in 2015 (USDA 2017).

Death percentages of young calves and the primary causes of death are similar in other countries. Investigators from Norway reported that $7.8 \%$ of calves died within the first year of life during 2005 (Gulliksen et al., 2009). Stillbirths were reported at $3.4 \%$ and overall mortality in liveborn calves was $4.6 \%$. Windeyer et al. (2014) studied herds from Minnesota and Ontario, Canada, and reported a preweaning heifer mortality of $3.5 \%$. In New Zealand, preweaning mortality risk in 32 seasonal calving herds on pasture was $5.7 \%$ for perinatal mortality $(<24 \mathrm{~h})$ and $4.1 \%$ for postnatal mortality (Cuttance et al., 2017). A systematic review of neonatal mortality ( $1 \mathrm{~d}$ of age to weaning) reported an incidence risk of 0.04 to 0.12 (Compton et al., 2017).

Although calf death loss estimates in the United States are higher than we would like, they represent an improvement in dairy heifer calf survival since the first NAHMS dairy study in 1992. The Dairy Heifer
Evaluation project in 1991-1992 and NAHMS dairy studies in 1996, 2002, and 2007 estimated dairy heifer calf losses preweaning, excluding stillbirth losses, at 8.4, $10.8,10.5$, and $7.8 \%$, respectively (USDA, 2008). This improvement in calf survival can likely be attributed to multiple changes in heifer calf management over that period. These changes have followed extensive research and aggressive dissemination of results to producers regarding colostrum quality and feeding, preweaning calf nutrition, maternity pen management, and prompt removal of calves from that contaminated area, and nursing calf housing, bedding, and ventilation.

\section{IMPROVING CALF HEALTH AND SURVIVAL ON INDIVIDUAL OPERATIONS}

The estimates of calf health and survival identified in the NAHMS studies represent averages for the industry. Therefore, some dairies have better calf performance and survival, whereas death loss of heifer calves on other dairies is high, demonstrating that individual dairies could likely improve calf health by adopting enhanced management methods. For instance, the percentage of stillbirths ranged from 3 to $8 \%$ for the 25 th and 75th percentiles in the NAHMS 2014 study (USDA, 2016). However, such improvements are best directed by analyzing and understanding the features that are most influential on that operation. Murray and Leslie (2013) review risk factors and strategies for improving newborn calf vitality.

Most causes of calf deaths can be mitigated by appropriate preventive care or well-tailored treatments, meaning that the typical death loss percentage could be decreased with improved management. For instance, calves with viral or protozoal scours, which results in water and electrolyte losses, can be treated and have a high probability of recovery if provided with aggressive fluid therapy. However, such management changes are best directed by a thorough analysis of causes of calf death, and current dairy calf record systems typically lack sufficient detail for these types of analyses. For the most recent NAHMS dairy study in 2014, when producers were asked to provide causes of death for their preweaned calves during a 1-yr period, only about $5 \%$ of deaths were reported as having an unknown cause (USDA, 2018). When the same question was asked about individual calves, as was done in the recent NAHMS Dairy 2014 Calf Component study, 25\% of deaths had unknown causes, the second highest percentage of all deaths after digestive disease (Urie et al., 2018). Calves that are treated for specific conditions and die are frequently categorized based on the clinical signs and reason for treatment; that is, the previous disease. This means that the recorded cause of death 
Table 1. Cause of death categories for the National Animal Health Monitoring System (NAHMS) Dairy 2014 and death loss studies

\begin{tabular}{ll}
\hline $\begin{array}{l}\text { NAHMS Dairy 2014 } \\
\text { (USDA, 2018) }\end{array}$ & $\begin{array}{l}\text { NAHMS Death Loss } \\
\text { (USDA, 2017) }\end{array}$ \\
\hline $\begin{array}{l}\text { Scours/diarrhea } \\
\text { Respiratory problems } \\
\text { Joint or navel problems }\end{array}$ & $\begin{array}{l}\text { Digestive problems } \\
\text { Respiratory problems }\end{array}$ \\
& $\begin{array}{l}\text { Metabolic problems } \\
\text { Mastitis }\end{array}$ \\
Trauma & Lameness or injury \\
Oameness or injury & $\begin{array}{l}\text { Other diseases } \\
\text { Calving-related problems }\end{array}$ \\
Calving problems & Poisoning \\
& Theft \\
Other known problems & Other nonpredator causes \\
Unknown causes & Unknown nonpredator causes \\
& Predator causes \\
\hline
\end{tabular}

is based on the owners' or workers' perceptions rather than on more accurate information such as necropsy findings.

Table 1 provides a list of death categories captured in the NAHMS Dairy 2014 study and comparable categories in the NAHMS death loss reports. These categories were formulated based on the types of data most commonly kept by dairy operators. These categories are not only generic but also poorly defined.

Digestive and respiratory diseases are common conditions that affect heifer calves, but the broad categories do not indicate the mitigating steps that need to be taken to reduce death losses. More specific information on the cause and circumstances surrounding calf deaths would be helpful in better analyzing patterns and implementing practices to prevent future deaths. Necropsy and laboratory diagnostic testing are 2 procedures that could be implemented to better understand cause of death in dairy calves. Necropsy of dead heifer calves, however, is not a common procedure in the United States; $11.3 \%$ of dairy operations performed any heifer necropsies and only $4.6 \%$ of heifer deaths were necropsied during 2013 (USDA, 2018).

It seems unlikely that producers and veterinarians can be persuaded to substantially increase necropsy and diagnostic submissions for calves in the short term. Alternatively, the process of analyzing risk factors for calf disease and death could be improved if there were more focus on recording the information and details that are necessary for analysis. Similar to the HACCP (hazard analysis and critical control points) system, information about risk factors or hazards for poor outcomes could be collected during the process of perinatal care. For outcomes, a more carefully constructed description of cause of death could be collected. We
Table 2. Key calf information to collect at the time of death

\begin{tabular}{ll}
\hline Information & Value \\
\hline Calf ID & \\
Date of death & Yes, no \\
Euthanasia & Yes, no \\
Necropsy & $1-15$, or category name \\
If yes, relevant findings & \\
Death category & \\
Notes & \\
\hline
\end{tabular}

hypothesize that a better categorization of death losses would stimulate heightened awareness of calf losses and create a rationale for improved analysis of on-farm risk factors that could be improved through management.

\section{PERINATAL RISK FACTORS AND DEATH LOSS OUTCOMES}

In October 2017, the primary author was approached by leadership of the Dairy Herd Improvement Association (DHIA) about convening a group of calf experts to identify calf death categories to be included in DHIA records. The coauthors of this paper were contacted and began engaging in a discussion on the most pertinent categories in late October. Personal experience and data from publications were used to construct the categories. Email discussions continued until a draft version of the categories was produced in January 2018 and presented to DHIA for evaluation. In addition to recording the cause of death, information was considered that would be helpful for analyzing patterns of calf death loss. Key information to be collected at the time of death is presented in Table 2.

In constructing the calf death categories, we focused on preweaning calves, because they are at the highest risk for illness and in the age group with the highest levels of mortality. Relative risk of death in weaned calves is very low compared with that in preweaning calves, and because death categories are listed in a temporal association with disease, the latter categories are more applicable to weaned calves.

Analysis of cause of death should also include information about predisposing factors for illness events to more carefully determine cause and effect and direct improved management. To this end, the following information should be recorded as part of the "calf birth certificate" data to bookend the beginning of life (Table 3 ), in addition to the "death certificate" concept promoted by McConnel and Garry (2017) and McConnel et al. (2019). An example calf birth certificate is presented in Figure 1.

The recording of these critical pieces of information is valuable in evaluating trends over time, such as the per- 
Table 3. Data to be recorded as part of a calf birth certificate in the recordkeeping system (see Figure 1 for example)

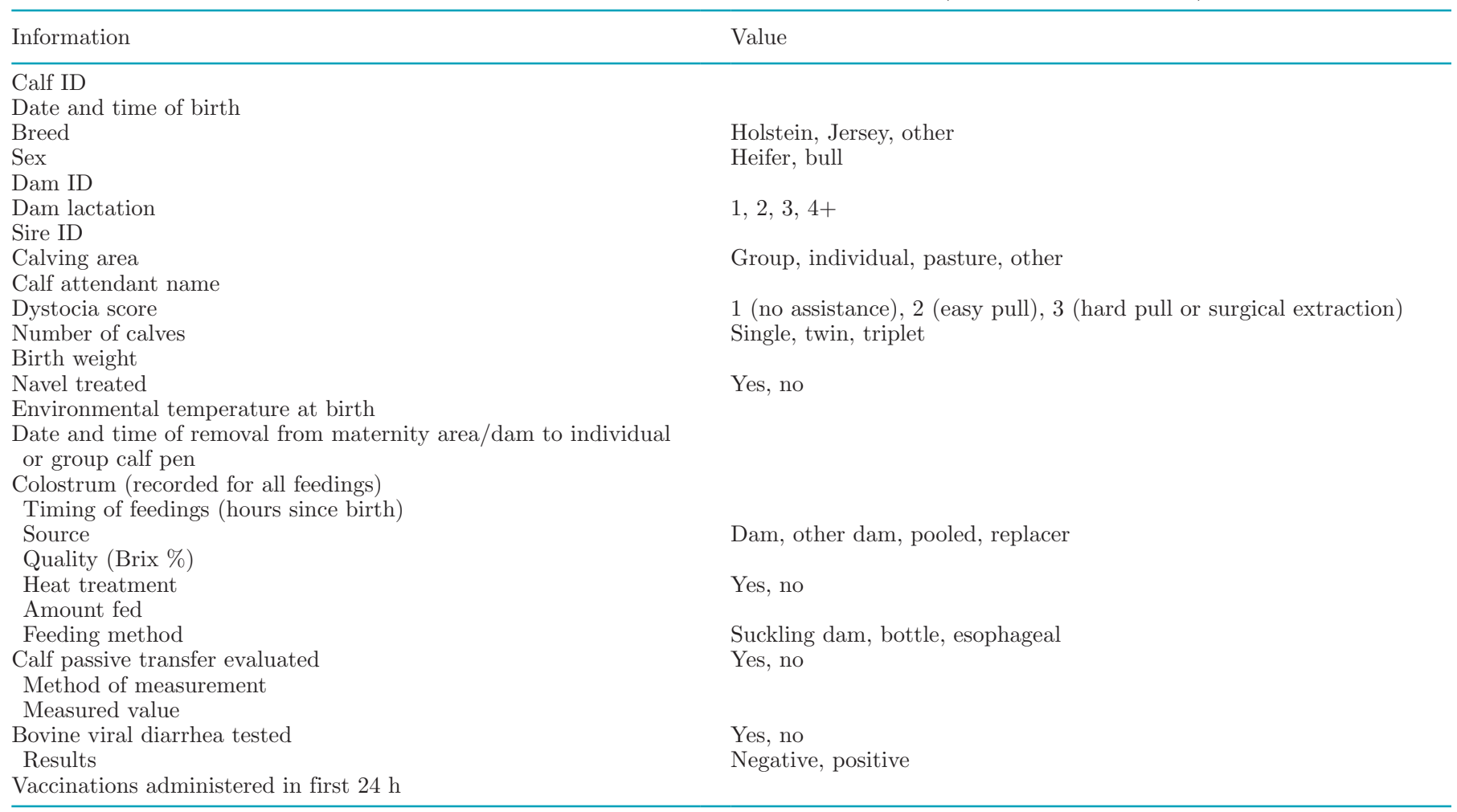

centage of dystocia births by dam lactation or morbidity and mortality events in dairy calves. For instance, if the number of calves having scours in the first 7 to $14 \mathrm{~d}$ of age increases, specific risk parameters around calving for sick or dead calves could be compared with those of healthy calves. Most of the information included on the birth certificate would be collected in the first $24 \mathrm{~h}$ of life. The exceptions would be test results for bovine viral diarrhea (BVD) and passive transfer that would be recorded at the time of reporting.

We proposed the list of 15 calf death categories that is presented in Table 4. A flowchart was developed to assist dairy personnel in choosing the correct death category based on the specific circumstances of each calf (Figure 2). The flowchart is constructed temporally so that calves that die early in life are captured quickly. Stillbirth events were broken into discrete categories because interventions for preventing deaths during and following delivery are different, including improved delivery methods and nursing care of dystocia-affected perinatal calves to minimize calf mortality. Once the category most likely representing the calf death is determined, then that category would be entered along with the other information in Table 2.

Multiple studies have shown that calves experiencing dystocia are at higher risk for immediate and long-term mortality and morbidity. The immediate mortality event, whether before delivery intervention, during the delivery process, or within the first $48 \mathrm{~h}$ after delivery, has been termed a "stillbirth" (Meyer et al., 2001; Cole et al., 2007). The long-term effects of dystocia include increased morbidity and mortality up to $30 \mathrm{~d}$ of age (Lombard et al., 2007). If not recorded, the dystocia event might not be associated with these long-term negative outcomes. Furthermore, defining calves that are born dead or die within $48 \mathrm{~h}$ of birth as stillbirths is commonly reported in the dairy literature and used when computing sire evaluations (Weigel, 2010). In our opinion, this method of categorizing stillbirths complicates the picture among calves that died in utero before calving, those having a difficult calving that died, and those that experienced a normal calving but did not transition to extrauterine life and died. Recording both dystocia and calves that are born dead (i.e., true stillbirths) is important, because the interventions would be different. Recording the severity of the dystocia, using the 3- or 5-point scale, is important, because the more difficult the calving, the higher the risk for negative health consequences.

The proposed calf death loss scoring categories classify stillbirths as those calves that are born dead. Such calves are then divided into dystocia- and eutocia- 


\section{Calf Birth Certificate Example}

\section{General Information:}

Calf ID:

Breed:

Dam ID:

Sire ID:
Birth date and time:

Sex:

Dam lactation: $\mathrm{am} / \mathrm{pm}$

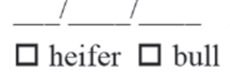

$\square 1 \square 2 \square 3 \square 4+$

\section{Calving Data:}

Calving area (check one):

Dystocia score (check one):

Number of calves (check one):

Was the calf born dead

(check one)?

Birth weight:

Navel treated (check one):

Environmental temperature at birth

Date and time of removal to calf pen $\square$ group pen $\square$ individual pen $\square$ pasture $\square$ other

Attendant:

$\square$ single $\square$ twin $\square$ triplet

$\square$ yes $\square$ no

If the calf was born dead please complete the calf death certificate.

$$
\begin{aligned}
& \overline{a \text { yes }}{ }^{\mathrm{lb} / \mathrm{kg}} \\
& { }^{\circ} \mathrm{F} /{ }^{\circ} \mathrm{C} \\
& \square
\end{aligned}
$$

Colostrum Feeding Record:

\begin{tabular}{|c|c|c|c|c|}
\hline & $1^{\text {st }}$ Feeding & $2^{\text {nd }}$ Feeding & $3^{\text {rd }}$ Feeding & $4^{\text {th }}$ Feeding \\
\hline Colostrum fed (check one): & $\square$ yes $\square$ no & $\square$ yes $\square$ no & $\square$ yes $\square$ no & $\square$ yes $\square$ no \\
\hline Time of feeding: & $\mathrm{am} / \mathrm{pm}$ & $\mathrm{am} / \mathrm{pm}$ & $\mathrm{am} / \mathrm{pm}$ & $\mathrm{am} / \mathrm{pm}$ \\
\hline Source (check one): & $\begin{array}{l}\square \text { dam } \square \text { other dam } \\
\square \text { pooled } \square \text { replacer }\end{array}$ & $\begin{array}{l}\square \text { dam } \square \text { other dam } \\
\square \text { pooled } \square \text { replacer }\end{array}$ & $\begin{array}{l}\square \text { dam } \square \text { other dam } \\
\square \text { pooled } \square \text { replacer }\end{array}$ & $\begin{array}{l}\square \text { dam } \square \text { other dam } \\
\square \text { pooled } \square \text { replacer }\end{array}$ \\
\hline \multicolumn{5}{|l|}{$\begin{array}{r}\text { Other Dam ID or } \\
\text { Replacer name }\end{array}$} \\
\hline Quality (Brix \%) & $\%$ & $\%$ & $\%$ & $\%$ \\
\hline Heat treated (check one): & $\square$ yes $\square$ no & $\square$ yes $\square$ no & $\square$ yes $\square$ no & $\square$ yes $\square$ no \\
\hline Amount fed: & $\mathrm{Q} / \mathrm{L}$ & $\mathrm{Q} / \mathrm{L}$ & $\mathrm{Q} / \mathrm{L}$ & $\mathrm{Q} / \mathrm{L}$ \\
\hline $\begin{array}{l}\text { Feeding method } \\
\text { (check all that apply): }\end{array}$ & $\begin{array}{c}\square \text { suckling dam } \\
\square \text { bottle } \square \text { esophageal }\end{array}$ & $\begin{array}{c}\square \text { suckling dam } \\
\square \text { bottle } \square \text { esophageal }\end{array}$ & $\begin{array}{c}\square \text { suckling dam } \\
\square \text { bottle } \square \text { esophageal }\end{array}$ & $\begin{array}{c}\square \text { suckling dam } \\
\square \text { bottle } \square \text { esophageal }\end{array}$ \\
\hline
\end{tabular}

\section{Health Record:}

\begin{tabular}{|l|l|l|l|l|}
\hline $\begin{array}{l}\text { Passive transfer status measured } \\
\text { (record measurement if tested): }\end{array}$ & $\square$ yes $\square$ no & Total Protein (g/dL) & Brix (\%) & Other \\
\cline { 3 - 5 } & & & & \\
\hline
\end{tabular}

BVD Tested (check one) $\quad \square$ yes $\square$ no

Result (check one): $\square$ negative $\square$ positive $\quad$ Retest (check one): $\square$ yes $\square$ no If BVD positive retest and euthanize if positive on both tests.

Vaccinations administered in first 24 hours:

Was the calf born alive but died before 24 hours of age (check one)?: $\quad \square$ yes $\square$ no

\section{Notes:}

If the calf died please complete the calf death certificate.

Figure 1. Example of a calf birth certificate. BVD = bovine viral diarrhea. 
associated stillbirths. The authors propose restricting the definition of stillbirth to describe calves born dead, rather than the current use, which describes calf deaths up to $48 \mathrm{~h}$ of age. In our proposed scheme, calves that are alive at birth and die within $48 \mathrm{~h}$ are not categorized as stillbirths. Calves that are injured during the calving process and die are recorded as experiencing dystocia and would be classified as dying from calving problems. Calves that are born alive, do not have traumatic injuries from the birthing process, and die within $48 \mathrm{~h}$ of birth would be classified as perinatal deaths. Most instances of perinatal death are attributable to physiological alterations and a consequence of failure to adapt to extrauterine life. To compare traditional stillbirth measures and measures under the proposed scheme, the deaths due to true stillbirths, calving problems, and perinatal deaths could be summed to approximate all deaths until $48 \mathrm{~h}$ of age - the current definition of stillbirth. Calves that are born alive but die within $48 \mathrm{~h}$ represent about 20 to $25 \%$ of stillbirths (USDA, 2009). If half of these calves can be saved with practical methods, it would result in an additional 75,000 to 85,000 calves that live beyond $48 \mathrm{~h}$.

In a paper on this subject, Mee (2013) relates that high calf death rates are an international welfare prob- lem, primarily referring to perinatal mortality (e.g., stillbirth or deaths within the first $48 \mathrm{~h}$ of life). He suggests 9 categories or reasons for stillbirths: (1) dystocia, (2) anoxia, (3) infection, (4) congenital defects, (5) omphalorrhagia (bleeding from the umbilical arteries), (6) premature placental separation, (7) trace element disorders, (8) other, and (9) unexplained.

Many of the categories suggested by Mee (2013) are similar to those proposed in the current paper. Calves experiencing a dystocia and born dead would be classified as dystocia stillbirths, whereas those experiencing a dystocia but dying within $48 \mathrm{~h}$ would be classified as having died from calving problems. Calves not experiencing a dystocia but born dead would be classified as eutocia stillbirths. Calves that die within $48 \mathrm{~h}$ of age from a eutocia calving would classified as perinatal mortality. This scheme allows for a more detailed account of the calf's experiences to be used in classifying the death while still having categories that can be summed to match the current definition of stillbirth.

Although the proposed birth certificate data and calf death categories are intended to assist in improving recordkeeping and analysis on individual dairies, a comprehensive farm-level data collection system would be useful for industry-wide analysis. In some

Table 4. Calf death loss categories and descriptions

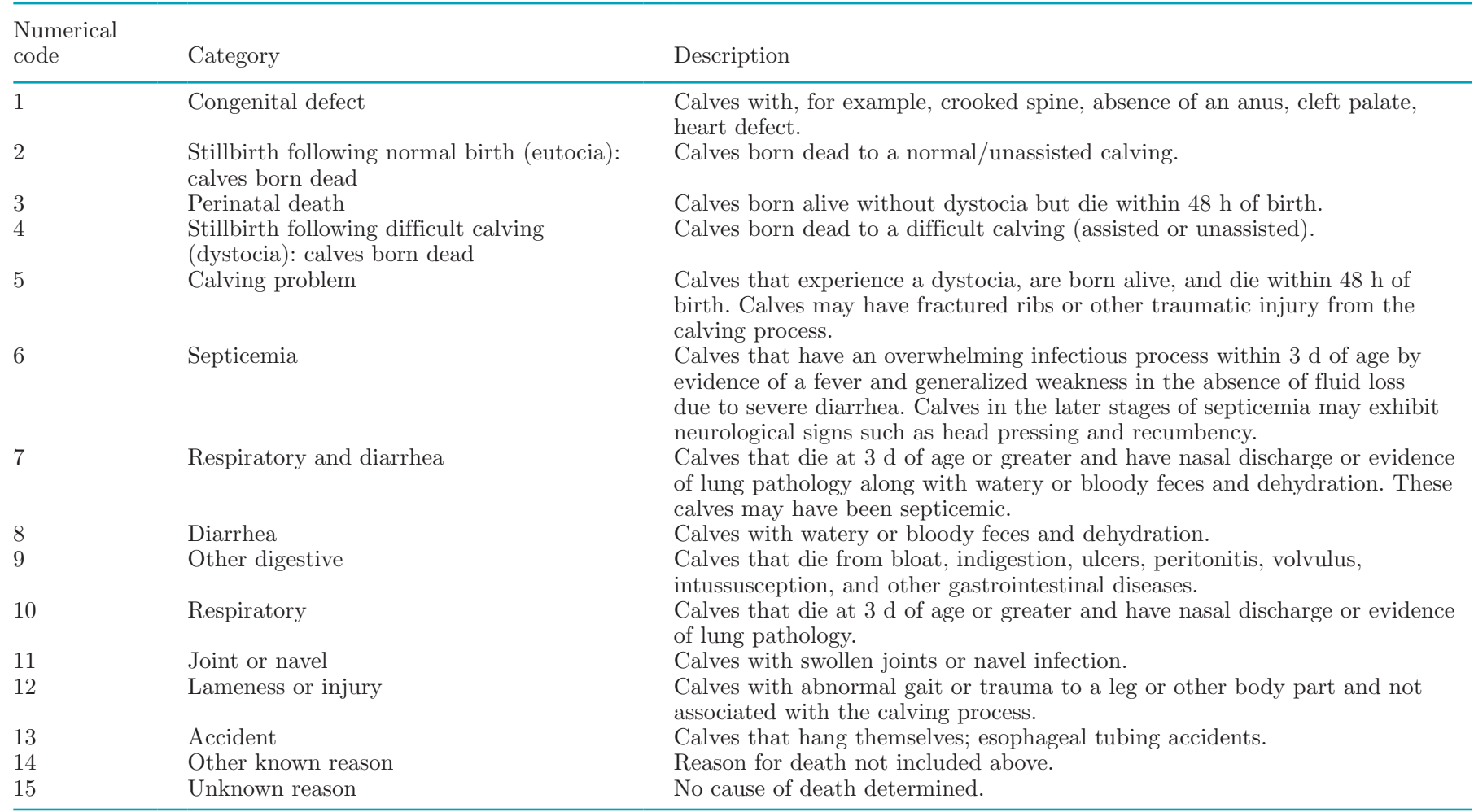




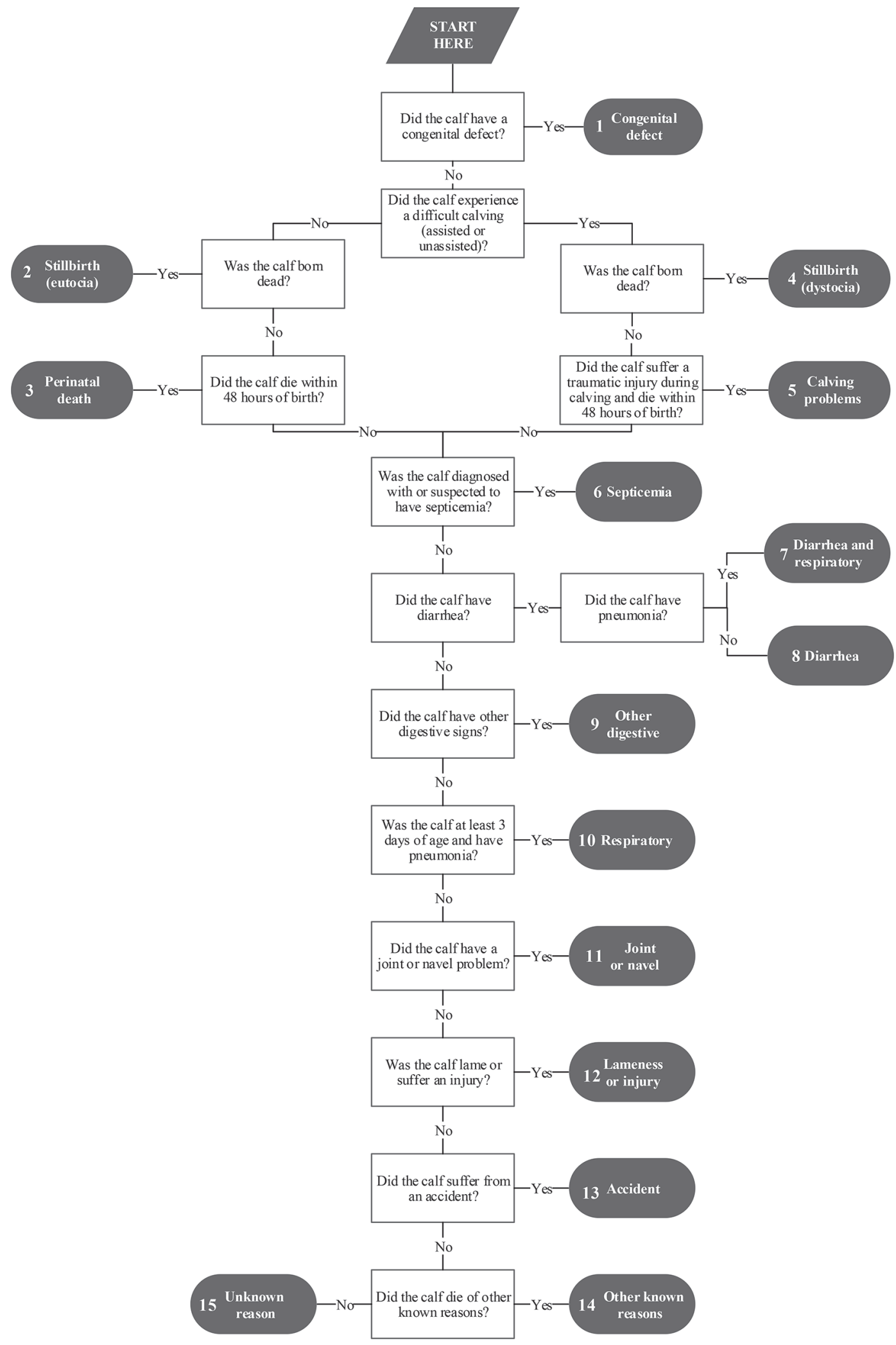

Figure 2. Flowchart for classifying calf death loss categories. 
countries, national registry systems collect more data on birth and death information than is currently available in the United States. More detail, such as is collected through these systems, could assist producers in managing health in dairy heifers. For example, a lethal genetic defect causing cholesterol deficiency in calves was detected through the use of a national cattle registry system in Europe (Menzi et al., 2016). Affected calves showed unresponsive diarrhea accompanied by hypocholesterolemia and died within weeks to months of age. The earliest known carrier of the recessive gene was a Canadian Holstein bull but the genetic defect was not identified in calves in Canada, likely because of the lack of recordkeeping and analysis.

\section{SUMMARY}

Death loss percentages of heifer calves in the US dairy industry represent a significant welfare issue and result in substantial production and financial losses. The majority of calf losses occur before weaning, with about $6 \%$ of calves dying at birth or the first 1 to $2 \mathrm{~d}$ after delivery and an additional $6 \%$ dying during the preweaning period. Many losses could be prevented with targeted management improvements. Producer education about improved colostrum feeding, calf nutrition, and calf hygiene have helped reduce calf losses over the last few decades. We suggest that more improvements would be made to enhance calf health and survival if producers had better information about the causes of death and some of the management features associated with losses on individual operations. Here, we define a proposed "calf birth certificate" that includes specific metrics of perinatal management and calf status that would be useful in identifying risk factors for calf morbidity and mortality. We also propose data collection and death loss categories that more specifically identify the cause of death. Ideally, necropsy examination would substantially improve identification of cause of death, but even without necropsy, attribution of cause of death can be improved by more carefully defining death loss categories for on-farm record systems.

\section{ACKNOWLEDGMENTS}

We thank the Dairy Herd Improvement Association, Duane Norman from the Council on Dairy Cattle Breeding, and the members of the Council's Pursuing Data Quality committee for bringing this discussion to the group. We also would like to thank Elizabeth Atwell, Craig McConnel, and Hirsh Dairy for the on-farm testing and refinement of the proposed death categories.

\section{REFERENCES}

Cole, J. B., G. R. Wiggans, and P. M. VanRaden. 2007. Genetic evaluation of stillbirth in United States Holsteins using a sire-maternal grandsire threshold model. J. Dairy Sci. 90:2480-2488.

Compton, C. W. R., P. T. Thomsen, T. E. Carpenter, C. V. C. Phyn, and S. McDougall. 2017. Invited review: A systematic literature review and meta-analysis of mortality and culling in dairy cattle. J. Dairy Sci. 100:1-16. https://doi.org/10.3168/jds.2016-11302.

Cuttance, E. L., W. A. Mason, J. McDermott, R. A. Laven, S. McDougall, and C. V. C. Phyn. 2017. Calf and replacement heifer mortality from birth until weaning in pasture-based dairy herds in New Zealand. J. Dairy Sci. 100:8347-8357. https://doi.org/10 .3168/jds.2017-12793.

Earley, B., K. Buckham Sporer, and S. Gupta. 2017. Invited review: Relationship between cattle transport, immunity and respiratory disease. Animal 11:486-492. https://doi.org/10.1017/ S1751731116001622.

Gulliksen, S. M., K. I. Lie, T. Løken, and O. Osterås. 2009. Calf mortality in Norwegian dairy herds. J. Dairy Sci. 92:2782-2795. https: //doi.org/10.3168/jds.2008-1807.

Hulbert, L. E., and S. J. Moisá. 2016. Stress, immunity, and the management of calves. J. Dairy Sci. 99:3199-3216.

Lombard, J. E., F. B. Garry, S. M. Tomlinson, and L. P. Garber. 2007. Impacts of dystocia on health and survival of dairy calves. J. Dairy Sci. 90:1751-1760.

McConnel, C. S., and F. B. Garry. 2017. Dairy cow mortality data management: The dairy certificate of death. Bovine Pract. 51:6472 .

McConnel, C., D. Nelson, C. Burbick, S. Buhrig, E. Wilson, C. Klatt, and D. Moore. 2019. Clarifying dairy calf mortality phenotypes through postmortem analysis. J. Dairy Sci. 102:4415-4426. https: //doi.org/10.3168/jds.2018-15527.

Mee, J. F. 2013. Why do so many calves die on modern dairy farms and what can we do about calf welfare in the future? Animals (Basel) 3:1036-1057. https://doi.org/10.3390/ani3041036.

Menzi, F., N. Besuchet-Schmutz, M. Fragnière, S. Hofstetter, V. Jagannathan, T. Mock, A. Raemy, E. Studer, K. Mehinagic, N. Regenscheit, M. Meylan, F. Schmitz-Hsu, and C. Drögemüller. 2016. A transposable element insertion in APOB causes cholesterol deficiency in Holstein cattle. Anim. Genet. 47:253-257. https://doi .org/10.1111/age.12410.

Meyer, C. L., P. J. Berger, K. J. Koehler, J. R. Thompson, and C. G. Sattler. 2001. Phenotypic trends in incidence of stillbirth for Holsteins in the United States. J. Dairy Sci. 84:515-523.

Murray, C. F., and K. E. Leslie. 2013. Newborn calf vitality: Risk factors, characteristics, assessment, resulting outcomes and strategies for improvement. Vet. J. 198:322-328. https://doi.org/10.1016/j .tvjl.2013.06.007.

Shivley, C. B., N. J. Urie, and J. E. Lombard. 2016. Management of dairy bull calves on U.S. dairy operations. J. Anim. Sci. 94:581. (Abstr.) https://doi.org/10.2527/jam2016-1210.

Urie, N. J., J. E. Lombard, C. B. Shivley, C. A. Kopral, A. E. Adams, T. J. Earleywine, J. D. Olson, and F. B. Garry. 2018. Preweaned heifer management on US dairy operations: Part V. Factors associated with morbidity and mortality in preweaned dairy heifer calves. J. Dairy Sci. 101:9229-9244. https://doi.org/10.3168/jds 2017-14019.

USDA. 2008. Dairy 2007, Part II: Changes in the U.S. Dairy Cattle Industry, 1991-2007. USDA-Animal and Plant Health Inspection Service-Veterinary Services-Center for Epidemiology and Animal Health-National Animal Health Monitoring System (USDAAPHIS-VS-CEAH-NAHMS), Fort Collins, CO. \#N481.0308. Accessed Aug. 31, 2018. https://www.aphis.usda.gov/animal_health/ nahms/dairy/downloads/dairy07/Dairy07_dr_PartII_rev.pdf.

USDA. 2009. Dairy 2007, Part IV: Reference of Dairy Cattle Heath and Management Practices in the United States, 2007. USDAAnimal and Plant Health Inspection Service-Veterinary ServicesCenter for Epidemiology and Animal Health-National Animal Health Monitoring System (USDA-APHIS-VS-CEAH-NAHMS), 
Fort Collins, CO. \#N494.0209. Accessed Aug. 31, 2018. https:/ /www.aphis.usda.gov/animal_health/nahms/dairy/downloads / dairy07/Dairy07_dr_PartIV.pdf.

USDA. 2016. Dairy 2014, Dairy Cattle Management Practices in the United States, 2014. USDA-Animal and Plant Health Inspection Service-Veterinary Services-Center for Epidemiology and Animal Health-National Animal Health Monitoring System (USDAAPHIS-VS-CEAH-NAHMS), Fort Collins, CO. \#692.0216. Special tabulation. https://www.aphis.usda.gov/animal_health/nahms/ dairy/downloads/dairy14/Dairy14_dr_PartI.pdf.

USDA. 2017. Cattle and calves death loss in the United States due to predator and nonpredator causes, 2015. USDA-Animal and Plant Health Inspection Service-Veterinary Services-Center for Epidemiology and Animal Health-National Animal Health Monitoring System (USDA-APHIS-VS-CEAH-NAHMS), Fort Collins, CO. \#745.1217. Accessed Aug. 31, 2018. https://www.aphis.usda .gov/animal_health/nahms/general/downloads/cattle_calves deathloss_2015.pdf.

USDA. 2018. Dairy 2014, Health and Management Practices on U.S. Dairy Operations, 2014. USDA-Animal and Plant Health Inspec- tion Service-Veterinary Services-Center for Epidemiology and Animal Health-National Animal Health Monitoring System (USDAAPHIS-VS-CEAH-NAHMS), Fort Collins, CO. Fort Collins, CO. \#696.0218. Accessed Aug. 31, 2018. https://www.aphis.usda.gov/ animal_health/nahms/dairy/downloads/dairy14/Dairy14_dr PartIII.pdf.

Weigel, K. 2010. Complete and accurate recording of calving ease and stillbirth data is key. Extension online. Accessed Aug. 31 2018. https://articles.extension.org/pages/11036/complete-and -accurate-recording-of-calving-ease-and-stillbirth-data-is-key.

Winder, C. B., C. A. Bauman, T. F. Duffield, H. W. Barkema, G. P. Keefe, J. Dubuc, F. Uehlinger, and D. F. Kelton. 2018. Canadian National Dairy Study: Heifer calf management. J. Dairy Sci 101:10565-10579. https://doi.org/10.3168/jds.2018-14680.

Windeyer, M. C., K. E. Leslie, S. M. Godden, D. C. Hodgins, K. D. Lissemore, and S. J. LeBlanc. 2014. Factors associated with morbidity, mortality, and growth of dairy heifer calves up to 3 months of age. Prev. Vet. Med. 113:231-240. https://doi.org/10.1016/j .prevetmed.2013.10.019. 